\title{
Story as Self
}

\section{Robert Malka ${ }^{1}$}

We begin with Nietzsche's lightning flash metaphor. ${ }^{2}$ From On the Genealogy of Morals:

And just as the common people separate lightning from its flash, and task the latter to be a deed, something performed by a subject, which is called lightning, popular morality separates strength from the manifestation of strength, as though there were an indifferent substratum behind the strong person which had the freedom to manifest strength or not. But there is no such substratum; there is no "being" behind the deed, its effect and what becomes of it; "the doer" is invented as an afterthought — the deed is everything. (GM I, S 13, 26, T) (F. t. Nietzsche 2018)

Pippin makes this compressed assertion into a claim: that the doer is in the deed rather than "behind" or "before" it. The doer is not separable from the deed itself; there is no Cartesian "inner" self separate and determinate, struggling for expression in an imperfect “outer" self (Pippin, 78). Today, we might describe this understanding of Nietzsche as expressivist, rather than intentional or causal. If this is the case, Pippin suggests, it is impossible to

[isolate] a subject's determinate intention...the determinate meaning of such an intention cannot be made out if isolated from a much larger complex of social and historical factors (Pippin, 77).

What, then, might be the basis of the temporal story linking a subject's manifestations and transformations, if (as Pippin asserts Nietzsche is saying) whatever is in these deeds is not a stable core or substantial self? If we cannot understand our actions outside a given context, what does it mean for us to say "we've" done something? And when we recall a coherent understanding of our previous actions - actions we at least understand to have been "ours" — what are we doing, precisely? Is it simply observation, a passive watchingof-our-actions? Or is there some dynamism, some ability to influence ourselves based on our understanding? How, finally, are we able to form stories that make sense to us and to others if we cannot make out any intentions?

To better understand what intention may mean to Nietzsche, we recall Twilight of the Idols:

\footnotetext{
${ }^{1}$ Robert Malka, N/A, United States. E-mail: rjmalka@gmail.com.

${ }^{2}$ Many thanks to Mr. Daniel Rodriguez for his review of my work and helpful comments.
} 
"One is necessary, one is a piece of fate, one belongs to the whole, one is the whole - there exists nothing which could judge, measure, compare, condemn our being, for that would be to judge, measure, compare, condemn the whole. But nothing exists outside the whole?' (TI, Four Great Errors, 8)

In addition to a complex of social and historical factors, we must understand the whole before we can understand our being — that is, our characters and lives, our communities and traditions, even our tradition's historical opposition to another tradition, just as we learn something about ourselves when we come into conflict with others. This raises the stakes of our "intentional" -- externally recountable -- stories: is it possible to have an 'accurate' view of ourselves?

Pippin suggests that others must register our deed in the way that we do in addition to seeing ourselves in our deeds (Pippin, 79). When we are "understood" -- seen as we want to be seen -- our feeling of power is increased. In a state of health, life naturally accumulates power and, partly in order to accumulate it, defines what it is. The feeling of power comes as much from our ability to convince others that we have it, as from our capacity to exert it. So our deeds and interpretations compete, cooperate, and align with endless other deeds and interpretations. This suggests an endlessly complex world, one with indeterminable meaning or meanings. We cannot examine ourselves through every perspective (through "the whole"), so we cannot ever finally know ourselves, or the final implications of our actions.

This is where our story begins. We use language with the intention of meaning what we say and saying what we mean to each other. When successfully understood, stories become a common ground, a linguistic foundation that allows for more layers of common ground to form:

...Words are acoustical signs for concepts; concepts, however, are more or less definite image signs for often recurring and associated sensations, for groups of sensations. To understand one another it is not enough that one use the same words; one also has to use the same words for the same species of inner experiences; in the end one has to have one's experience in common.... In all souls an equal number of often recurring experiences come to be predominant over experiences that come more rarely: on the basis of the former one understands the other, quickly and ever more quickly-the history of language is the history of a process of abbreviation-and on the basis of such quick understanding one associates, ever more closely (BGE, 268).

If concepts are image signs for recurring and associated sensations, then stories are a string of concepts understood together. Stories are the deeds of language, an outgrowth of our tendency to abbreviate, and allow us to associate or dissociate from ourselves and others. For example, the ideas of "suffering" and "joy" are ultimately abbreviations contingent upon our social, historical, and "personal" understanding of those image signs. They make sense of our experiences, insofar as "we" — ourselves and those with whom we share those experiences in common - see ourselves in them.

Commonality, Nietzsche seems to be saying, also allows us to "extend" our personal boundaries, our understanding of ourselves, to others who share the same understanding: 
What "I" know, "they" know, and thus there is a "we" in our recurring experiences. As a result, we begin to associate more closely with those shared experiences - the results of our deeds - more often, and push away from less understandable or contemptible, because not our, experiences.

Story, in sum, is an evaluation: it finds us a place in the world, putting us somewhere within (or without) our context. Our story allows us to invent ourselves through concepts like morality which, as Nietzsche says, has been the most effective tool for us to take control of our evolution thus far. ${ }^{3}$ Our story also allows us to be outside of ourselves, to examine "who we are" from myriad perspectives, to frame our deeds - "our" selves — in endlessly nuanced ways. But we've returned to Pippin's question: Without the inner self, how precisely did our story begin?

Things are complicated by a line in Thus Spoke Zarathustra:

But the thought is one thing, the deed is another, and another yet is the image of the deed. The wheel of grounds ["causality"] does not roll between them (TSZ, I:6).

According to Nietzsche, not only do our thoughts not cause our actions, but what we make of our actions is also not caused by our thoughts or our actions. Intuitively, we might describe our story, the flash that follows the lightning, as follows: It began as a thought; we expressed it aloud or articulated it to ourselves; from there it became a deed; and finally it changes or reinforces how we see the world. Since this can't be true for Nietzsche, particularly because "the deed is everything," how does our story manifest itself? Is it thought, deed, or image?

Our story can best be understood primarily as another deed, especially if wielded consciously as a tool to transform oneself or one's environment - but not just a deed. Our story objectifies our experience: it affects how we understand our deeds. It must operate on the level of image, expressing in signs what it is we've done. How this is possible, if there is no clear causality between deed and image, remains unclear. We will focus on our story as a deed before we turn to the complexity surrounding what else it could be.

Over a lifetime, Nietzsche wrote and re-wrote his own story, Ecce Homo being his last known, semi-ironical attempt. He wrote at least six autobiographies while in his twenties ${ }^{4}$, saying of this tendency:

When I see my own writings, it is as if I have heard old travel adventures that I have forgotten. Let us see to it that we monumentalize our whole lives in this way (KSB 6, 97).

Stories allow one to travel, so to speak, by interpreting one's events and experiences in such a way that they become, to their own selves and to others, a different person altogether. The self-narrative, used intentionally, can allow a person to transform themselves, ultimately making one see themselves and their actions in an aesthetically beautiful way, as

\footnotetext{
${ }^{3}$ Thanks to Lise Van Boxel and her essay, The Motion That is Man, for this insight.
}

${ }^{4}$ Blue 2016, pgs 2-5. 
a piece of art. Understood in this way, story is only "story" when it's embodied, when it's lived out. As Nietzsche insists, this is noble, life-affirming work:

I want to come to regard everything necessary as beautiful - so that I will become one of those who makes everything beautiful. Amor fati: from now on, let that be my love! I do not want to wage war against the ugly. I do not want to accuse anyone, I do not even want to accuse the accusers. May averting my eyes be my only negation! All in all, and on the whole, someday I hope only to be an affirmer! (JS, 276)

For Nietzsche, learning is not an intellectual exercise, e.g. thinking a mantra repeatedly. Rather, learning to "see as beautiful what is necessary" entails a kinesthetic process whereby one, for example, writes out a story of oneself and then "tries it on" by acting in such a way as to validate the truth of that story. Perhaps stories are different based on whether or not one or several drives and affects are predominating in one moment, and others in another. In articulating a story, as with any other deed, we also heighten and accentuate certain of our tendencies, and lessen others. Learning in this case would therefore mean: making a story — the disparate actions and perceptions that encompass a perspective we're embodying - habitual. In self-narration one becomes both the "teacher and creator" of oneself by identifying "the memory of [one's] good moments and [finding] their context, the golden chain of [oneself]" (emphasis mine) (KSA 9:11[297], p.555).5 "Teacher and creator" is a wonderfully compressed phrase: One invents the story one intends to live by, putting together the raw materials to validate it, and then teaches embeds it - in oneself through repeated action.

One can just as easily identify with one's worst experiences, and reside in such environments. Zarathustra's ape is one example. He is a fool who speaks hatefully against the city, but hypocritically resides in it. He stays because his identity, his tendency to despise, is reliant on it, and is moreover a reflection of it. Rather than move out and change his relationship to the city, he expresses its spirit whole-heartedly, to which Zarathustra says:

Why did you live for so long in the swamp that you yourself had to become a frog and toad? Does a putrid and spumy swamp-blood not now flow through your own veins, that you have learned to croak and blaspheme thus? ... Is the sea not full of grass-green islands? I despise your despising; and if you have warned me-why did you not warn yourself? (TSZ, III:7)

So if one's worst moments sustain one's "golden chain," one learns and embodies an equally impactful self-transformation.

Story can reflect one's true needs, even if those needs are self-destructive. It depends, it seems to me, on which story a subject feels best reflects them, which story they most see themselves in and want to see themselves in, moment to moment. One's deeds and context, insofar as they give us permission to rewrite our story of ourselves, helps us engage with new, often surprising understanding:

${ }^{5}$ Credit to Ms. Kaitlyn Creasy from her essay, "Making Knowledge the Most Powerful Affect." 
The great epochs of our life come when we gain the courage to rechristen our evil as what is best in us (BGE, 116).

As Kaitlyn Creasy suggests, this means enhancing or minimizing certain affects attached to our drives — turning a contemptuous affect into a proud affect, and so on. This also opens up the pliability of our "selves," in the name of enabling new stories:

"I have done that," says my memory. "I cannot have done that," says my pride, and remains inexorable. Eventually - memory yields (BGE, 68).

Our memory, says Nietzsche, is far from a permanent recording of life-events: rather, it is shaped, interpreted, warped, enhanced, and even repressed altogether by one's drives and the affects tethered to them. The affect Nietzsche cites is a type of pride, a desire to cut away what we insist should not emanate from us, and go contrary to our story of ourselves. This fight exists even if the actions originate from our dominating, organizing drive. For example, our environment could condemn our deeds so strongly that, having internalized this condemnatory affect and orientation, we attempt to be rid of what we see in ourselves. Ultimately, this force is so strong that we cannot help but bow to it:

To our strongest drive, the tyrant in us, not only our reason bows but also our conscience (BGE, 158).

Self-narration — story - is essential because it helps us control a force that will reign whether we are conscious of it or not. In order for it to mean anything, to be anything in order for us to learn from and through it — it must be a deed done consciously, meaning that we take ownership of it and see ourselves in it. This can take the form of writing it out, "trying it on," expressing actions in such a way as to "reflect" what we see in this story of ourselves. This act of articulating ourselves in one way, then another, transforms us and our interaction with the world. We can more adeptly interpret our histories and previous transformations, helping us to enhance or minimize certain affects to support or negate our organizing drives. ${ }^{6}$ So we see the need for stories: What, then, grounds them? In particular, what allows a person to see themselves in who they "used to be," even if they no longer share any qualities in who they were?

This is tricky because Nietzsche is far from suggesting that there is no consistency in the doer of a deed. Even if lightning changes shape, form, or place, its flash, however different, is still recognizable as a flash. There is something about us that is undeniably "us," something that allows us to feel that our consistency in the world is not an illusion, even if we are nothing like what we used to be or could be. It is helpful to review some of Pippin's insights further: He describes our commitments and pledges, "what we care about" and the depth of those commitments, as

... [occurring] within ongoing, already norm-governed practices that themselves depend on [our] basic, or depth, commitments, which cannot finally be the implications of other commitments. ... [this basic orientation in life is phrased] in terms of eros and erotic attachment, [and it is] prereflective and volitional... (Pippin 69).

\footnotetext{
${ }^{6}$ Creasy, 225.
} 
48 Story as Self

To reinforce this, we look again at Beyond Good and Evil, 268:

Which group of sensations is aroused, expresses itself, and issues commands in a soul most quickly, is decisive for the whole order of rank of its values and ultimately determines its table of goods. The values of a human being betray something of the structure of his soul and where it finds its conditions of life, its true need. (Emphasis mine.)

In other words, there is some pre-reflective, volitional way in which our commitments are organized such that we have what Nietzsche calls a "true need." We have sensations, subtle and otherwise, that accommodate the meeting of this need. One's deeds, stories, self, and context are all ultimately arranged, insofar as a person can arrange and express such things, according to this need. This true need, because it is pre-reflective and primordial, is not easily changeable; it is what allows us in the first place to act and react to our contexts in the particular way that we do, even as our context shapes the particular tendencies towards meeting our true need. At the very least, this is the fundamental basis of our lives: What we care about, how much we care about it, and the fact that we care at all - the degree of our eros, and the need that keeps it alive. This need, it seems to me, is one basis for the consistency of our temporal stories, assuming that our need, as is suggested here, does not easily change over our lifetime. The moments we recognize ourselves as transformed are the moments we understand something essential about our true need, and the ways in which our environment is and is not capable of helping us meet it.

This may help us understand why the image of our deeds is not fundamentally causally related to our actions. Perhaps the images we have of our deeds partly stem from the organization of our souls, tendencies that, while they can be enhanced or minimized gradually with time, are not easily changeable. When Nietzsche describes a people as "...nature's detour to produce six or seven great men.... and then to get around them," perhaps he means that we who are not one of those six or seven, are tending towards certain proclivities, which those great men will express in superior form (BGE, 126). Deeds, done habitually, become genealogy, genetic and generational, more innate than learned. This is true for story too. An individual can take hold of such deeds using story and chain their deeds, previous, present, and future, in novel ways that transform them, even if such stories aren't necessarily coherent.

I suggest in fact that stories do not have to cohere, that there need not be a "for the sake of which." This is clear when we examine a prolonged state of madness, in which actions are jagged, confused, and seem wholly without basis. But even a cursory examination of Nietzsche shows that caring about something, having a need, is not enough to fulfill or articulate the conditions of that need, and so is not necessarily enough to enable a coherent story, a coherent interpretation of one's life. The Pale Criminal is a clear example of this:

An image made this pale man pale. Equal to his deed was he when he did it: but its image he could not endure after it was done. He now saw himself always as doer of a single deed. Madness I call this: The exception now became for him the essence (TSZ, I:Ø).

The parable goes on to describe the Pale Criminal's judges, and the misunderstanding they have of this man, culminating in his judgment of himself, the death knell for his continued 
becoming. His story can't cohere because he fully internalized his context, which made clear that he ought to see himself only as the doer of a single deed, borne of his dominating drive: in this case, a murder. He thus can no longer see himself as a continuous becoming; his context no longer gives him permission to explore and meet his need. He fails to see himself as able to become something other than what he is understood to be any longer. Generally speaking, one can fail at meeting this need, and fail catastrophically. So can a society. Nietzsche says that the former often happens, and we are in danger of the latter (Pippin, 29).

The fate of a person is recognizably all the more tragic, risky, and uncertain when misunderstandings appear between him and his own people, those with whom he is supposed to share an identical understanding of image-signs. It is hard to maintain a personal story when one cannot place it into the world, when world does not understand or respond to it. Therefore the stakes for finding the places and people that share our language, the image-signs that we identically understand — "our people" — is very high. And, as said in BGE 268, it is far from inevitable:

The human beings who are more similar, more ordinary, have had, and always have, an advantage; those [who are] more select, subtle, strange, and difficult to understand, easily remain alone, succumb to accidents, being isolated, and rarely propagate. One must invoke tremendous counter-forces in order to cross this natural, all two natural progressus in simile, the continual development of men toward the similar, ordinary, average, herd-like-common!

We've discussed a subject's context, and described how much a person can readily find himself within his context, rather than solely within his body. His world doesn't just shape him: It also holds and coheres his story, his past, present, and future, and the boundaries to which he can ultimately understand or extend himself. So it seems right to suggest that, in cases such as the Pale Criminal, one can in fact lose their ability to maintain a story of themselves that makes sense, even to them: To be cast out or impugned in a society is so severe to a human being precisely because they are cut off from ways of understanding themselves, from groundings in which their actions, drives, and affects can make sense. Stories can thus also be protective, insofar as they allow us, by rationalizations, deceptions, and excuses, to continue living:

... it is impossible that a bad person should grow out of such good soil. If one of the good nevertheless does something unworthy of the good, then one has recourse to excuses; one blames a god, for example, saying that he struck the good man with delusion and madness ( $H A H, 45)$.

A tradition, in this case, gives a subject a proverbial "safety net." This safety net allows one to place their actions as outside of themselves, in the form of an immediately understandable, socially acceptable excuse. ("Confessing" in Christianity works in a roughly analogous way.) One can then metabolize their drives in ways that are healthier. Rather than become trapped in time by obsessing over a particular image of what one has done, one can externalize the drive as "fate," or "the will of the Gods." In this way, we see the second basis for the temporal stories we use to connect ourselves to past, present, and future: Our environment - the people around us — the soil from which we're born, and, when we don't have immediate access to our environment (as in exile), the memories we 
have and create of those environments. Such is one example of the ways in which our environment maintains our story for us. And if we, like the Pale Criminal, don't have that external safety net, we will invent it:

Thus speaks the scarlet judge: "But why did this criminal murder? He wanted to rob.” But I say to you all: his soul wanted blood, not loot; he was thirsting for the joy of the knife! But his meager reason was unable to grasp this madness and it won him over. "What is the point of blood!" It said; "do you not at least want to steal something too? Or to take revenge?" And he listened to his meager reason: like lead did its speech lie upon him — and so he robbed when he murdered. He wanted not to be ashamed of his madness (TSZ, I:6).

This story dictating that murder is forbidden was so powerful in the Pale Criminal's case that he deceived himself by inventing an alternative interpretation of his desires. ${ }^{7} \mathrm{He}$ wanted to rob. Context is essential for understanding one's temporal story, not only because one's deeds might ripple throughout the world long after, but because it creates the conditions for deception, invention, and reinvention. And when there is no apparent basis to our story — when we turn against our primary drive or drives in part because of our environment's rejection of us, and our attempts to fulfill our true need (oftentimes because it rejects the validity of our need) — we seem to lose the ability to stay coherent altogether.

As is the case here, stories can be mere rationalizations, things which disguise by way of describing what Nietzsche repeatedly calls the foreground opinion or experience. They're things invented to hide the drive from the person himself, an interpretation suggested to minimize certain affects or shape the deed's particular impact in the world (since having it be understood a certain way by another person changes the action). But they are also essential, not only to the person for whom the story has a presumed preeminence (because it's "about him") but for the world that needs to understand him. That it's essential for person and world means that a person's story neither belongs solely to himself, nor does it belong only to world; there is an endless, recursive interaction "between" them, whose relationship story plays a nuanced part in shaping.

\section{Conclusion}

Grounded in Pippin's diction, we use the word "story" to describe an experience that is in fact two things, not causally connected: A deed — creation — and a way of shaping our image of the deeds that we do. The grounds of our temporal story lie in ourselves and in the world. We can be "teacher and creator" of ourselves by rewriting our story, given what we know and the contexts in which we reside, to enhance or minimize certain aspects of ourselves or the world and so get a fresh view of who we are. This way, we can transcend what we were and become closer to articulating and meeting our true needs. Yet our stories do not simply reside "within us;" Nietzsche's insistence that the subject is in the deed also means that the basis of our story of ourselves resides in the world, in particular those environments in which we spend time and do things. This environment can be literal climates and peoples — and it can be socio-cultural, as with traditions and mores. When

${ }^{7}$ For an exploration of what Nietzsche means when he says a person can deceive themselves, see Chapter Five of Nietssche, Psychology, and First Philosophy. 
we live somewhere, we adopt the perspectives of certain traditions, communities, and histories, and use those to inform ourselves about ourselves. When we find ways to see what is "evil" in us as what is best in us, we experience transformation. Our memory and our need are the threads that hold our stories together, even through periods of growth so profound that we no longer share a likeness to who we were before. Still, our memory is pliable, and depending on our drives, we freely manipulate it to fit the stories we'd like to tell, both to ourselves and to others. While this consistency is usual and expected, it is possible for a temporal story to stop cohering, as with madness, or with people who are no longer able to become. For our temporality and our fluidity is what makes us human; that we continue to create and produce stories, that we continue to invent reasons to invent ourselves, is ultimately the primordial tendency behind all of our stories, and the reason why eros - caring about something — matters so much to Nietzsche. One cannot become a work of art if one does not continue to paint. This would be a misfortune from which we would all suffer; for "art is the highest task and the proper metaphysical activity of this life" (The Birth of Tragedy, Foreword).

\section{Works Cited}

Blue, Daniel. 2016. The Making of Friedrich Nietzsche: The Quest for Identity. Cambridge: Cambridge University Press.

Creasy, Kaitlyn. Autumn 2019. "Making Knowledge the Most Powerful Affect: Overcoming Affective Nihilism." The Journal of Nietzsche Studies (Penn State University Press) 50 (2): 210-232.

Nietzsche, Friedrich, ed. Colli, Giorgio and Montinari, Mazzini. 1988. Complete Works. Critical Study Edition (Sämtliche Werke. Kritische Studienausgabe), 2nd edn., 15 vols. Munich: dtv; Berlin and New York: de Gruyter.

Nietzsche, Friedrich, ed. Colli, Giorgio and Montinari, Mazzino. 1986. All Letters, Critical Study Edition (Sämtliche Briefe. Kritische Studienausgabe). Berlin and New York: de Gruyter.

Nietzsche, Friedrich, ed. Ridley, Aaron and Norman, Judith. 2005. Nietzsche: The Anti-Christ, Ecce Homo, Twilight of the Idols, and Other Writings. Cambridge: Cambridge University Press.

Nietzsche, Friedrich, trans. Fadiman, Clifton. 1995. The Birth of Tragedy. New York: Dover Publications, Inc.

Nietzsche, Friedrich, trans. Hill, R. Kevin. 2018. The Joyous Science. Great Britain: Penguin Random House UK.

Nietzsche, Friedrich, trans. Hollingdale, R.J. 2003. Beyond Good and Evil. London: The Penguin Group.

- 1996. Human, All Too Human: A Book for Free Spirits. Cambridge: Cambridge University Press.

Nietzsche, Friedrich, trans. Kaufmann, Walter. 1989. Beyond Good \& Evil: Prelude to a Philosophy of the Future. New York: Vintage Books.

Nietzsche, Friedrich, trans. Parkes, Graham. 2005. Thus Spoke Zarathustra: A Book. for Everyone and Nobody. Oxford: Oxford University Press.

Nietzsche, Friedrich, trans. Pearson, Keith Ansell, and Diethe, Carol. 1994. On the Genealogy of Morals: A Polemic. Cambridge: Cambridge University Press.

Pippin, Robert B. 2010. Nietzsche, Psychology, and First Philosophy. Chicago: University of Chicago Press. 
52 Story as Self

\section{Abbreviations:}

BGE - Beyond Good and Evil

GM - On the Genealogy of Morals

HAH - Human All Too Human

JS - The Joyful Science

KSA - The Complete Works

KSB - The Complete Letters

TI - Twilight of The Idols

TSZ - Thus Spoke Zarathustra 